\title{
DAMPAK LEMBUR TERHADAP \\ PRODUKTIFITAS TENAGA KERJA KONSTRUKSI \\ (Sebuah Studi Literatur)
}

Lenggogeni

\begin{abstract}
Abstrak
Tulisan ini berisi ulasan kembali mengenai dampak yang terjadi akibat lembur terhadap produktifitas tenaga kerja pada pelaksanaan proyek konstruksi. Definisi dari produktifitas tenaga kerja pada proyek konstruksi adalah rasio dari jam kerja tenaga kerja sebagai input terhadap hasil kerjanya sebagai output sementara definisi dari lembur adalah jadwa kejra yang diperpanjang lebih dari 40 jam perminggunya. Menurut beberapa literature dan penelitian yang dilakukan mengenai lembur, besarnya penurunan yang terjadi pada produktifitas tenaga kerja yang diakibatkan oleh lembur adalah 10-15\%. Dampak dari lembur terhadap produktifitas tenaga kerja dapat dibagi dua, yaitu dampak langsung dan dampak tidak langsung. Dampak langsung adalah kelelahan pada tenaga kerja yang juga dapat menyebabkan kecelakaan kerja, sedangkan dampak tidak langsung adalah timbulnya gangguan dan hambatan pada pelaksanaan pekerjaan proyek, antara lain kekurangan material, kekurangan alat dan peralatan, dan terjadinya kepadatan pada lokasi konstruksi.
\end{abstract}

Kata kunci: produktifitas, tenaga kerja, lembur, proyek konstruksi

\section{Pendahuluan}

Industri konstruksi telah dilaksanakan sejak beratus-ratus tahun yang lalu oleh manusia, karena manusia merupakan pembangun yang kompulsif dan mempunyai kemampuan untuk mengembangkan ketrampilan membangunnya. Sejalan dengan berkembangnya ilmu pengetahuan dan pengalaman, kemampuan manusia untuk membangun suatu struktur bangunan juga meningkat secara ukuran maupun kompleksitasnya. Pada masa sekarang ini, setiap kehidupan manusia di bumi dibantu oleh konstruksi-konstruksi bangunan dengan berbagai bentuk dan fungsi, seperti bangunan, jalan, bendungan, pelabuhan, dan lain-lain, yang kesemuanya merupakan

Dampak Lembur Terhadap Produktifitas Tenaga Kerja Konstruksi (Lenggogeni, Dosen Jurusan Teknik Sipil FT- UNJ) 
pendukung bagi kelancaran dan kemudahan hidup manusia (Clough, 1986). Dapat disimpulkan bahwa selama manusia ada di bumi, maka pembangunan konstruksi tetap akan berjalan dan berkembang untuk menunjang kehidupan manusia.

Komponen tenaga kerja merupakan bagian dari sumber daya proyek konstruksi di samping uang, mesin, dan material. Komponen ini merupakan variabel yang terbesar dan tidak dapat diperkirakan sehingga banyak menuntut komitmen terhadap waktu dan perhatian dari tim manajemen. Menurut Halpin dalam bukunya, tenaga kerja memiliki empat aspek besar yang berhubungan dengan manajemen proyek konstruksi, sehingga untuk benar-benar mengerti pengaturan dan kontrol tenaga kerja sebagai sumber daya, manejer proyek harus mengetahui semua aspek tersebut, yaitu aspek organisasi ketenagakerjaan, aspek hukum ketenagakerjaan, aspek biaya tenaga kerja, dan aspek produktifitas tenaga kerja (Halpin, 1998). Dalam tulisan ini, aspek yang akan dibahas adalah aspek keempat, yaitu aspek produktifitas tenaga kerja berkenaan dengan lembur yang dilakukan pada proyek konstruksi.

Produktifitas sendiri masih sulit untuk didefinisikan secara jelas, tetapi menurut para ahli, secara umum produktifitas dapat diartikan sebagai perhitungan dari efisiensi dalam penggunaan sumberdaya atau dengan kata lain produktifitas adalah perhitungan dari efisiensi pemanfaatan sumber daya (sebagai input) untuk memproduksi suatu barang dan atau jasa (sebagai output). Produktifitas dilakukan pada saat proses produksi untuk menghasilkan suatu output yang telah direncakan. Input dari proses produksi tersebut adalah berupa tenaga kerja, material, peralatan, dan modal (Lavender, 1996). Dalam proyek konstruksi, produktifitas biasanya diasumsikan sebagai produktifitas tenaga kerja, yaitu satuan pekerjaan yang dihasilkan atau selesai oleh tenaga kerja per-jam kerja (Halligan, 1992).

Banyak hal yang menyebabkan produktifitas tenaga kerja di proyek konstruksi mengalami penurunan, salah satunya adalah adanya jam lembur. Thomas dan Raynar menyatakan bahwa lembur adalah kegiatan bekerja tenaga kerja diluar jam yang telah ditentukan sesuai dengan kesepakatan manajemen (Thomas, 1997). Jam lembur pada pelaksanaan proyek konstruksi biasanya disepakati oleh pihak manajemen proyek dalam rangka mempercepat penyelesaian proyek tersebut. Dari beberapa penelitian yang 
dilakukan oleh para ahli dibidang konstruksi, lembur merupakan salah satu masalah penyebab terjadinya penurunan produktifitas tenaga kerja. Berdasarkan uraian di atas, tulisan ini bertujuan untuk mengulas kembali dampak-dampak yang terjadi dengan adanya lembur bagi para tenaga kerja terhadap produktifitas tenaga kerja di proyek konstruksi.

\section{Produktifitas}

\section{Definisi Produktifitas}

Seperti telah diuraikan sebelumnya, definisi produktifitas sulit ditentukan. Tetapi berdasarkan pendapat beberapa ahli, produktifitas secara umum dapat didefinisikan sebagai perhitungan dari efisiensi dalam penggunaan sumberdaya. Dengan kata lain dapat ditarik pemahaman bahwa : produktifitas setara dengan kuantitas dari hasil dibagi dengan kuantitas dari masukan (Lavender, 1996; Oglesby, 1989).

Produktifitas $=\frac{\text { Kuantitas Output }}{\text { Kuantitas Input }}$

Produktifitas dilakukan pada saat proses produksi untuk menghasilkan suatu output yang telah direncakan. Input dari proses produksi tersebut adalah berupa tenaga kerja, material, peralatan, dan modal. Secara jelas digambarkan sebagai berikut (Lavender, 1996) :

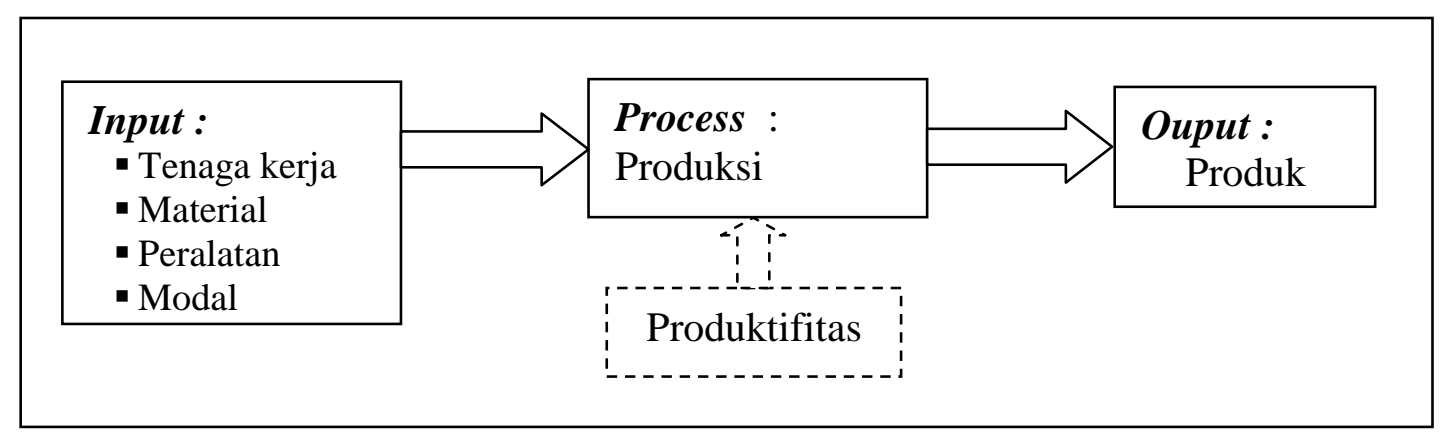

Gambar 1. Proses Input-Output Produktifitas

Secara konseptual, definisi di atas adalah benar, tetapi sangatlah sulit untuk menghitung produktifitas dalam prakteknya. Hal ini disebabkan karena setiap input biasanya dihitung dalam satuan yang berbeda, misalnya : tanah

Dampak Lembur Terhadap Produktifitas Tenaga Kerja Konstruksi (Lenggogeni, Dosen Jurusan Teknik Sipil FT- UNJ) 
dalam hektar, pekerja dalam jam, batu bata dalam ribuan, peralatan dalam kapasitas, dan lain-lain. Untuk itu, biasanya yang diambil sebagai perhitungan adalah sumber daya manusia, dimana akhirnya statistik dari produktifitas diekspresikan dengan ouput per unit dari input tenaga kerja. Thomas mendefinisikan produktifitas pada proyek konstruksi sebagai rasio dari jam kerja tenaga kerja sebagai input terhadap hasil kerjanya sebagai output (Thomas, 1992).

\section{Produktifitas Tenaga Kerja}

Produktifitas dalam proyek konstruksi sangat dipengaruhi oleh produktifitas tenaga kerja, yakni banyak pekerjaan yang dapat dilaksanakan oleh seorang pekerja ataupun regu kerja dalam suatu periode waktu yang sudah ditentukan [Barrie, 1995 : 189].

Produktifitas sebagai suatu konsep menunjukkan adanya kaitan antara hasil kerja dengan satuan waktu yang dibutuhkan untuk menghasilkan suatu produk dari seorang tenaga kerja. Seorang tenaga kerja dianggap produktif jika mampu menghasilkan suatu output yang lebih banyak dari tenaga kerja lain dalam satuan waktu yang sama. Dengan kata lain, dapat disimpulkan bahwa seorang tenaga kerja menunjukkan tingkat produktifitas yang lebih tinggi bila ia mampu menghasilkan produk yang sesuai dengan standar yang telah ditetapkan (Ravianto, 1985). Hal tersebut dapat terlihat dalam rumus sebagai berikut :

$$
\text { Produktifitas Tenaga Kerja }=\frac{\text { Jumlah hasil produksi }}{\text { Satuan waktu }}
$$

Thomas mengemukakan perhitungan produktifitas tenaga kerja dibagi dalam beberapa kategori yaitu model ekonomi, model spesifik, dan model yang berorientasi pada aktivitas. Model terakhir inilah yang banyak digunakan para kontraktor, dimana satuan dari output adalah merupakan spesifikasi jenis pekerjaan. Satuan yang digunakan adalah meter kubik, ton, atau meter persegi. (Thomas, 1990). Seperti dapat terlihat, produktifitas didefinisikan dalam banyak cara yang merefleksikan pandangan yang berbeda-beda pada industri konstruksi. 
3. Faktor-faktor yang Menyebabkan Penurunan Produktifitas Tenaga Kerja

Berdasarkan penelitian para ahli, faktor-faktor yang menyebabkan penurunan produktifitas tenaga kerja pada proyek konstruksi sangatlah beragam dan banyak sekali.

Iman Soeharto mengungkapkan bahwa faktor-faktor tersebut adalah :

a. Kondisi fisik lapangan

b. Supervisi, perencanaan dan koordinasi

c. Komposisi kelompok kerja

d. Kerja lembur

e. Ukuran besar proyek

f. Kurva pengalaman

g. Kepadatan pekerja

(Soeharto, 1997 ).

Penelitian yang dilakukan oleh Thomas dkk., menyatakan bahwa produktifitas tenaga kerja dapat dipengaruhi juga oleh banyak sekali faktorfaktor yang diantaranya adalah : manajemen kontraktor, manajemen material, gangguan pada pekerjaan, perubahan pekerjaan, dan cuaca yang buruk (Thomas, 1998).

James Rowings, dalam penelitiannya menyebutkan bahwa faktor-faktor yang menyebabkan menurunnya produktifitas tenaga kerja dibagi menjadi tiga kelompok, yaitu :

1. Faktor manajemen, termasuk di dalamnya adalah tim proyek, manajemen pengendalian, metode dan peralatan, ketersediaan material, komposisi pekerja, urutan pekerjaan, dan jadwal lembur.

2. Faktor proyek yang dikerjakan, termasuk di dalamnya adalah spesifikasispesifikasi yang berlaku, desain-desain tertentu, jumlah kru, pengulangan pekerjaan, kondisi area proyek, dan cuaca.

3. Faktor tenaga kerja, termasuk di dalamnya adalah insentif, semangat, daya tahan tubuh, serikat kerja, kualitas tenaga kerja, ketidakhadiran, dan lainlain. (James Rowings, 1996).

Kondisi yang tidak diantisipasi pada proyek konstruksi kadang-kadang juga merupakan salah satu penyebab menurunnya produktifitas tenaga kerja, misalnya cuaca yang buruk, jadwal lembur, kekurangan atau keterlambatan material, dan lain-lain. Tetapi, berdasarkan penelitian dan pengalaman kerja,

Dampak Lembur Terhadap Produktifitas Tenaga Kerja Konstruksi (Lenggogeni, Dosen Jurusan Teknik Sipil FT- UNJ) 
terlihat bahwa menurunnya produktifitas tenaga kerja bukan selalu dikibatkan oleh kondisi yang tidak terduga, seperti yang dijelaskan di atas (Halligan, 1992).

Dari pernyataan di atas, banyak sekali faktor yang mempengaruhi produktifitas tenaga kerja yang diungkapkan oleh para peneliti dan para ahli dibidang konstruksi, baik dalam bentuk jurnal ataupun dalam bentuk buku. Tetapi dapat terlihat bahwa lembur selalu merupakan bagian dari faktor-faktor tersebut, sehingga dapat disimpulkan bahwa lembur memang merupakan salah satu faktor penyebabnya terjadinya penurunan produktifitas tenaga kerja pada pelaksanaan pekerjaan proyek konstruksi.

\section{Lembur}

1. Hal-hal yang Menjadi Penyebab Lembur

Di Indonesia, tenaga kerja konstruksi pada umumnya bekerja sejak pukul 8.00 pagi hingga pukul 16.00 setiap harinya termasuk juga hari Sabtu dan Minggu. Waktu bekerja diluar jadwal tersebut dihitung sebagai waktu lembur. Lembur terbagi menjadi dua, yaitu lembur berdasarkan jumlah jam perminggu dan jumlah jam perhari, dimana lembur berdasarkan jumlah jam perminggu berarti pekerja bekerja lebih dari 40 jam seminggu, dan lembur berdasarkan jumlah jam perhari berarti pekerja bekerja lebih dari 8 jam perharinya (Thomas, 1992).

Thomas yang melakukan penelitian mengenai lembur di Amerika mendefinisikan lembur sebagai perpanjangan waktu kerja lebih dari 40 jam seminggu yang direncanakan oleh manajemen proyek untuk mempercepat progres pekerjaan pada suatu proyek konstruksi (Thomas, 1997).

Lembur direncanakan oleh pihak manajemen proyek dikarenakan adanya keterlambatan dalam pelaksanaan proyek sehingga untuk mempercepat pelaksanaan proyek konstruksi dibuatlah jam lembur sehingga proyek dapat selesai pada waktunya. Dampak positif dari lembur adalah tercapainya target waktu penyelesaian proyek sesuai dengan kontrak sehingga kontraktor sebagai penyedia jasa konstruksi dapat terbebas dari denda yang telah disepakati. Disisi lain, lembur di proyek konstruksi sering dilakukan sebagai bujukan untuk menarik tenaga kerja bekerja pada proyek tersebut. Ketidakefisienan tenaga kerja akan terjadi ketika banyaknya pekerjaan yang harus dikerjakan, khususnya jika dibarengi dengan tekanan untuk 
mempercepat jadwal penyelesaian. Menurut Helander, meskipun ada dampak positif jangka pendek dengan dibuatnya jam lembur, konsekwensi jangka panjangnya biasanya menjadi suatu gangguan dalam proses konstruksi (Helander, 1981).

2. Dampak Lembur terhadap Produktifitas Tenaga Kerja

Penelitian mengenai dampak-dampak lembur terhadap produktifitas tenaga kerja yang dapat dijadikan suatu pegangan sangat sulit dibuat karena sebenarnya ada banyak faktor yang dapat mempengaruhi produktifitas tenaga kerja seperti yang telah diuraikan sebelumnya.

Hasil penelitian-penelitian oleh para ahli mengenai lembur ini menunjukkan bahwa dampak dari lembur akan menyebabkan menurunnya produktivitas tenaga kerja rata-rata sebesar $10 \%$. Thomas menyatakan bahwa dari beberapa studi yang dilakukan oleh para ahli sejak dari tahun 1960an didapat laporan bahwa efisiensi dan produktifitas tenaga kerja konstruksi akan menurun sebesar 10 - 15\% untuk peningkatan waktu lembur sebesar 50 jam, 60 jam dan 70 jam perminggunya (Thomas, 1992). Gambar 2 adalah grafik yang menggambarkan penurunan produktifitas tenaga kerja yang melakukan pekerjaan listrik akibat lembur berdasarkan jumlah jam perminggu dengan masa kerja 50 jam dan 60 jam. Dapat terlihat dari grafik bahwa terjadi penurunan yang signifikan pada produktifitas akibat jam lembur setiap minggunya.

Dampak Lembur Terhadap Produktifitas Tenaga Kerja Konstruksi (Lenggogeni, Dosen Jurusan Teknik Sipil FT- UNJ) 


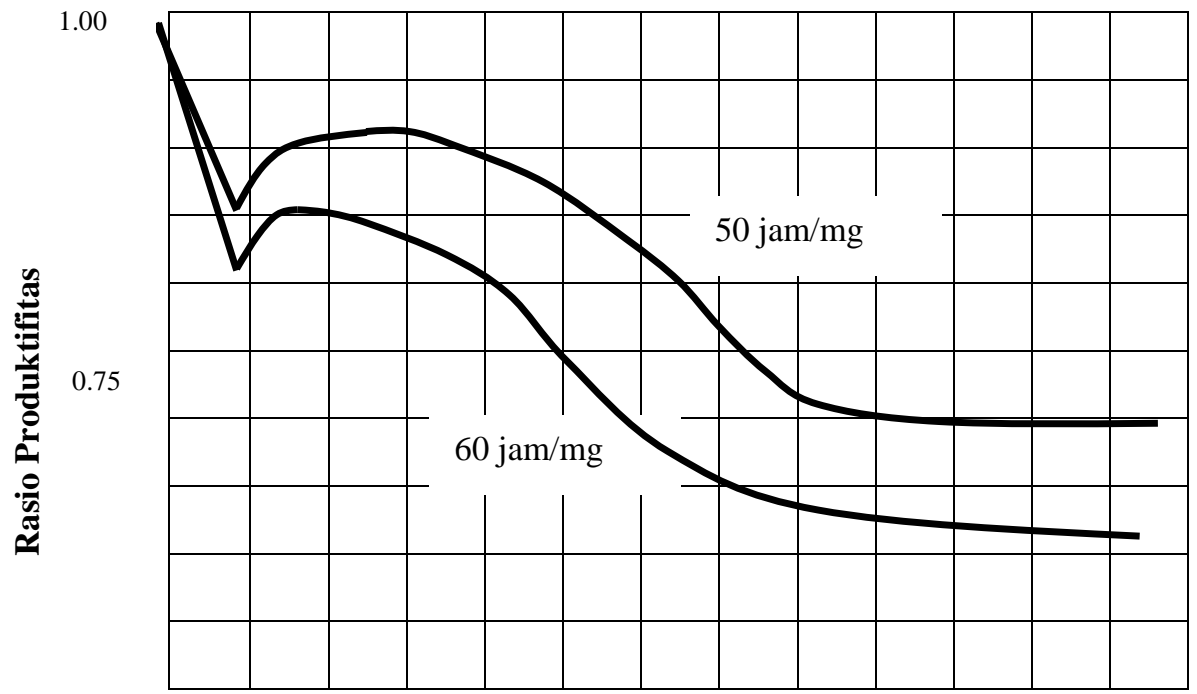

0.50

5

10

Minggu

Gambar 2. Dampak kumulatif lembur terhadap produktifitas untuk 50 jam dan 60 jam kerja per minggu

Sumber : Helander, 1 y81

Penelitian oleh Adrian pada tahun 1987 mengenai penurunan produktifitas tenaga kerja konstruksi yang diakibatkan oleh lembur berdasarkan jumlah jam perhari dapat terlihat pada grafik berikut ini : 


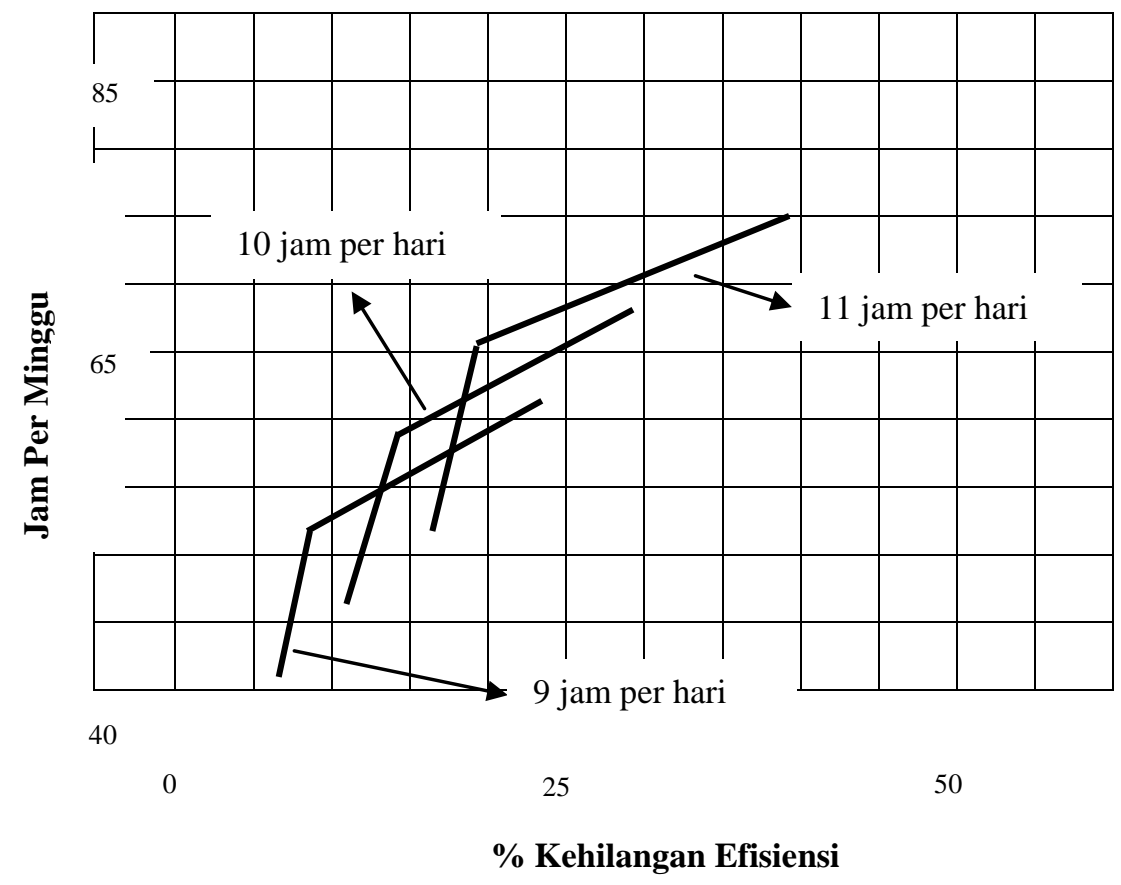

Gambar 3. Dampak Kumulatif Lembur Terhadap Produktifitas Tenaga Kerja Berdasarkan Jam Kerja Perhari untuk 21 Hari

Sumber: Thomas, 1992.

Lebih jauh, dampak lembur terhadap produktifitas tenaga kerja di proyek konstruksi terbagi menjadi dua, yaitu dampak langsung dan dampak tidak langsung. Dampak langsung yang terjadi akibat adanya lembur adalah kelelahan yang dialami oleh tenaga kerja. Menurut Oglesby, jika periode pekerjaan berjalan normal, maka kelelahan tidak berpengaruh langsung terhadap produktifitas kecuali tenaga kerja tersebut mengambil pekerjaan sampingan sehingga terpaksa bekerja sepanjang minggu. Tetapi dengan adanya lembur berkepanjangan, kelelahan yang dialami tenaga kerja menjadi faktor timbulnya kecelakaan-kecelakaan kerja, menurunnya produktifitas tenaga kerja, dan menurunnya kualitas pekerjaan (Oglesby, 1989). Penelitian lain yang dilakukan Thomas menunjukkan bahwa adanya lembur terus menerus dalam jangka waktu lebih dari 3 sampai 4 minggu secara pasti akan menimbulkan kelelahan pada tenaga kerja dan menjadi pemicu menurunnya produktivitas tenaga kerja (Thomas, 1997).

Dampak Lembur Terhadap Produktifitas Tenaga Kerja Konstruksi (Lenggogeni, Dosen Jurusan Teknik Sipil FT- UNJ) 
Di samping dampak langsung, lembur juga berdampak tidak langsung terhadap pelaksanaan proyek konstruksi. Thomas menyatakan, secara jelas dapat terlihat bahwa akibat adanya lembur bukan saja hanya produktifitas tenaga kerja yang terkena dampaknya, tetapi juga timbulnya gangguangangguan (disruption) terhadap komponen-komponen sumber daya lain yang akhirnya secara tidak langsung mempengaruhi produktifitas tenaga kerja (Thomas, 1992). Dapat disimpulkan bahwa lembur merupakan faktor tidak langsung yang menjadi penyebab munculnya variabel-variabel lain yang dapat mengganggu proses pekerjaan di proyek konstruksi. Untuk lebih jelasnya dapat dilihat pada diagram berikut :

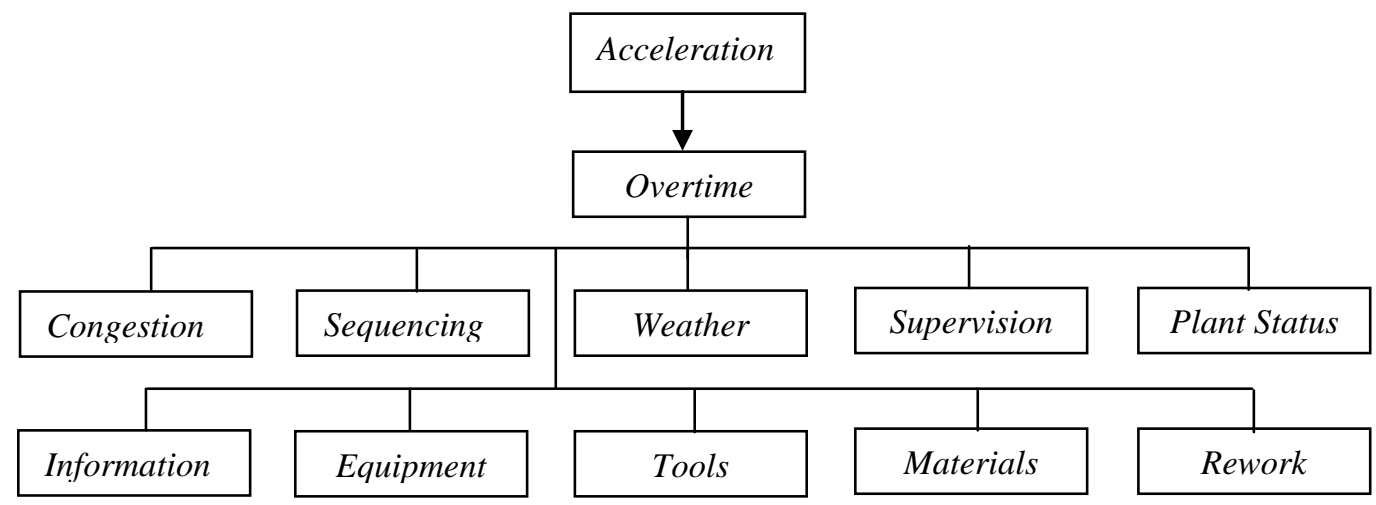

Gambar 4. Factor Model for Work Environment

Sumber : Thomas, 1997.

Diagram di atas menjelaskan bahwa variabel-variabel lain yang dapat terganggu akibat adanya lembur selain cuaca, karena cuaca tidak berhubungan dengan lembur. Misalnya, material dibutuhkan dalam jangka waktu yang lebih cepat, alat dan peralatan konstruksi menjadi lebih banyak dibutuhkan, dan tuntutan informasi manajemen harus diproses lebih cepat. Dari penelitian mengenai gangguan-gangguan (disruption) akibat lembur tersebut, Thomas membuat indeks variabel jenis-jenis gangguan yang sangat dipengaruhi oleh lembur, yaitu :

1. Ketersediaan Alat (Equipment Availability)

2. Ketersediaan Peralatan (Tool Availabililty)

3. Ketersediaan Material (Material Availability)

4. Pekerjaan Ulang (Rework)

5. Kepadatan lokasi (Congestion) 
Dari kelima variabel di atas yang paling besar terkena dampaknya adalah rework. Berdasarkan dari analisa mengenai gangguan-gangguan tersebut, dijelaskan bahwa akibat lembur menyebabkan kesulitan bertambah dalam penyediaan sumber daya, seperti material, alat, dan peralatan, sehingga secara tidak langsung akan mempengaruhi produktifitas tenaga kerja dalam melaksanakan pekerjaannya.

\section{Kesimpulan}

Komponen tenaga kerja merupakan bagian dari sumber daya proyek konstruksi di samping uang, mesin, dan material. Dalam pelaksanaan proyek konstruksi, tenaga kerja selalu dihubungkan dengan produktifitas sebagi salah satu aspek penting. Produktifitas tenaga kerja sendiri dapat didefinisikan secara beragam oleh para ahli sehingga secara garis besar dapat diartikan sebagai rasio dari jam kerja tenaga kerja sebagai input terhadap hasil kerjanya sebagai output.

Banyak hal yang dapat mempengaruhi naik turunnya produktivitas tenaga kerja pada pelaksanaan proyek konstruksi, salah satunya adalah lembur. Lembur adalah perpanjangan waktu kerja tetap yang direncanakan oleh manajemen proyek untuk mempercepat progres pekerjaan pada suatu proyek konstruksi dimana perpanjangan waktu ini dapat dibagi berdasarkan jam kerja perhari dan jam kerja perminggu. Berdasarkan penelitian para ahli, kedua pembagian ini sama-sama berdampak terhadap menurunnya produktifitas tenaga kerja baik secara langsung maupun tidak langsung. Dampak langsung yang terjadi akibat lembur adalah kelelahan yang dialami pekerja sehingga menjadi faktor timbulnya kecelakaan-kecelakaan kerja, menurunnya produktifitas tenaga kerja, dan menurunnya kualitas pekerjaan.

Dampak tidak langsung lembur terhadap produktifitas tenaga kerja adalah timbulnya disruption yang mengganggu kelancaran pelaksanaan proyek seperti ketersediaan alat dan peralatan, ketersediaan material, terjadinya rework, dan terjadinya congestion. 


\section{DAFTAR PUSTAKA}

Barrie, Donald S. dan C. Paulson Boyd. Manajemen Konstruksi Profesional, Penerbit Erlangga, Jakarta, 1989.

Clough, Richard H. Construction Contracting. Hohn Wiley \& Sons, New York, 1986.

Halligan, David W., et.al. Action Response Model and Lose of Productivity in Construction. Jurnal ASCE, vol. 120, 1992.

Halpin, Daniel W. dan Ronald Woodhead,. Construction Management. John Wiley \& Sons, Inc. 1998.

Helander, Martin. Human Factors Ergonomics For Building. John Wiley \& Sons, New York, 1981.

Neil, James M., Construction Cost Estimating for Project Control, Prentice-Hall Inc., New York, 1982.

Oglesby, Clarkson H., et.al. Productivity Improvement In Construction, McGraw-Hill Inc., New York, 1989.

Ravianto, Produktifitas dan Teknologi, Lembaga Sarana Informasi dan Produktifitas, Jakarta, 1985.

Thomas, H. Randolph et.al. Modelling Construction Labor Productivity, Jurnal Construction Engineering and Management, ASCE, vol. 116, 1990.

Thomas, Randolph. Effects of Scheduled Overtime on Labor Productivity. Jurnal Construction Engineering and Management, ASCE, vol. 118, 1992.

Thomas, Randolph dan Karl A. Raynar,. Scheduled Overtime and Labor Productivity : Quantitative Analysis. Jurnal Construction Engineering and Management, ASCE, vol. 123, 1997. 